\title{
CORRESPONDENCE
}

\section{High book prices}

SIR, - It is not just a berserk economy that is to blame for the high price of books. A colleague of mine expressed horror at the price proposed for a hard-back that he had intended for students, and asked why it could not be printed as a paperback. The answer was: "If it sells well then we shall publish a cheap edition". The Russians must be laughing at our marketing.

Yours faithfully,

PhILIP J Stewart

University of Oxford, UK

SIR, - The leader entitled "Are Books too Expensive"' (24 April page 649) was a wayward attempt at analysing a problem of great concern to everyone involved in publishing.

We were told that for the price of a skipped lunch we could once walk out of a bookshop with a few titles under our arm; perhaps we could be supplied with the actual year when this was possible. Let us assume it was 1962 , before the boom in science publishing. I asked two colleagues who had not read the article how much a cafeteria lunch of say three courses might have cost in 1962; one said 3/-, the other said $2 / 6$. I then checked records for the prices of monographs published in that year; a book of 256 pages cost an average $42 /$-. To walk out of the shop with one monograph, the author would therefore have had to skip 143 / - lunches.

How many lunches would the author have to skip now? We have just published a monograph of 256 pages at $£ 15.00$ and a simple three course lunch seems to cost around $£ 1.25$. The author would actually have to skip two fewer lunches today!

For those who would like a more serjous analysis the graph (based on figures supplies by the Publishers' Association) shows how the average price of books published in Britain has risen since 1970 . In the same period the UK Retail Price Index has risen a little more, just over $300 \%$. Average earnings have increased by more than the RPI since 1970 , but perhaps what the author should be complaining about 300

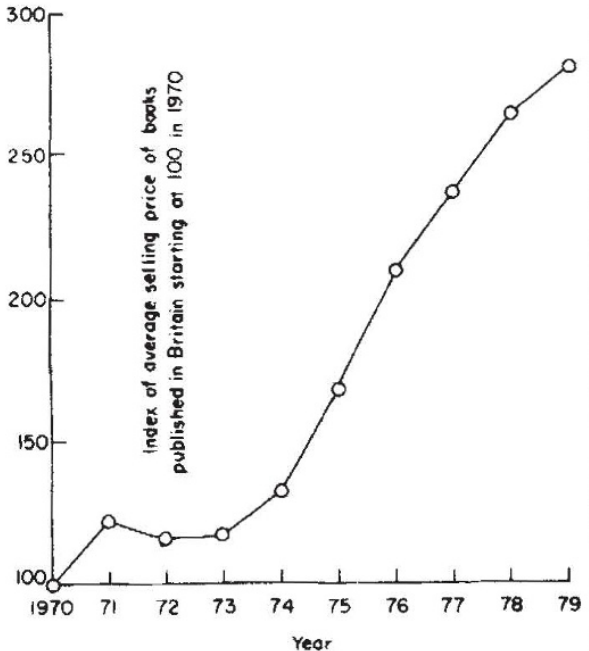

is that the average earnings of the book-buying population have probably slipped in relation to the rest of the population.

It is suggested that we should show restraint over symposia and monographs and avoid duplication. Symposia and monographs can, in fact, be published profitably if overheads are kept to a minimum as explained in the New Scientist (21 June 1979 page 1013) and the right number is printed, but most publishers are leaving these to a few companies which concentrate on specialist works. The vast majority of publishers would prefer to sell more copies of fewer titles but as sales of individual titles are decreasing, the response from some publishers has been to publish more titles to maintain turnover. The Soviet Union avoids duplication by controlling publication through central committees. The members of these committees are undoubtedly exceptionally talented but as the author points out, such a system cannot always be right in predicting which book will be essential to the development of a subject.

The real problem for British-based science publishers is that, although they are trying to hold down their prices, the value of the pound abroad is hitting the export market which takes around 60-75 per cent of production. Our books are becoming too expensive in some overseas markets. Our export market has also been weakened by the rise of indigenous publishing houses moving from producing translations of successful English language texts to books written by local authors. Students are prepared to pay more for texts in their first language and aimed specially at their courses. This is a healthy development in publishing as a whole, but it means that the publishers working in the English language can no longer assume that their books are

automatically international products and the first choice for students in many parts of the world.

Publishers can adapt to the problem of high selling prices resulting from the high value of the pound abroad by producing abroad; indeed many are already doing so. This however could permanently damage the UK printing industry. The curent wave of redundancies in publishing could be quickly followed by further unemployment amongst printers.

$$
\text { Yours faithfully, }
$$

$$
\text { ROBERT CAMPBELL, }
$$

Blackwell Scientific Publications

Osney Mead, Oxford, UK

\section{No gas guzzling}

SiR, - In your leading article of 17 April about energy conservation, you say that the "Gas Board . . . advertises to encourage us to use more energy",

The fact is we do precisely the opposite and just what you advocate. Your article is headed "Conserve energy, conserve cash". One of our slogans, widely used, is: "Save Gas, Save Money"'. Our publicity has plugged an energy conservation line for many years now. Moreover, since early last summer, no promotion of gas or gas appliances has been pursued that would build up gas load at the peak. On the contrary, television advertising about using gas efficiently has appeared throughout the winter months and is being followed by a campaign on similar lines in the national press at present. The efficient use of gas is one of our key objectives. Yours faithfully,

Public Relations Department

F W PLOWMAN British Gas Corporation

\section{Responsibility for nuclear weapons}

SIR, - Despite rising international tension there is little public debate about Britain's policy on nuclear and other modern weapons, especially in comparison with the impassioned campaigns for and against nuclear energy. And yet while nuclear energy is at worst a long-term threat to the quality of our civilisation, nuclear weapons could obliterate it in half an hour.

We have lived quietly with this peril for more than twenty years, during which the policy of deterrence has not failed. But there are several disturbing new developments that require urgent discussion, especially by scientists. First, the government's decision to consider producing chemical weapons; second, the government's decision to consider spending $£ 5,000$ million replacing Polaris nuclear submarines and missiles with the Trident system; third, the government's reaffirmation that its policy is to offer virtually no protection to civilians in the event of war; fourth, the government's decision to allow cruise missiles to be stationed in Britain; fifth, the increased accuracy of guidance systems (which could tempt the Russians or Americans into considering a first strike against each other's missiles)

The scientific community must play an important part in the extensive discussions that these ominous developments ought to provoke. In particular we should put under close scrutiny the activities of our colleagues who carry out weapons development. Lord Zuckerman has argued first, that their technical innovations have created a new situation, undermining deterrence by making all-out war a seriously-considered policy option, and, second, that the implementation of new weapons systems is often at the instigation of scientists rather than of the military. No longer should it be claimed as in the Second World War that military scientists are helping their side to win, nor, as in the 1950 s that they are building up an effective deterrent. Instead, it should be recognised that the contribution of scientists to warfare has entered a third phase, in which their prolific inventive capacity is itseif a powerful destabilising influence.

The consequences of the arms race continuing unchecked are so dire as to make it imperative for us to overcome the paralysing hypnosis induced by our sense of helplessness as individuals. As a small beginning we invite scientists to take the following steps:

1. To oblige those of our colleagues who devise and advocate new weapons of mass destruction to stand up and justify their work (as their counterparts in the nuclear energy industry are having to do).

2. To inform our students (and ourselves!) of the far-reaching and complex relationship between military technology and progress in 'pure' science.

3. To initiate informed discussion on weapons development in our various institutions and professional bodies and to make our own view clear. Those opposed to further weapons development might consider discouraging students from applying to enter military research establishments.

4. To support currently faltering international attempts towards arms control.

5. To promote public discussion by making MPs aware of our fears and encouraging them to play an active role in forming sane weapons policies.

\section{Yours faithfully,}

Michael Berry, ALWYN EADES DAVID FIEL.D. TIMOTHY POSTON GORDON REECE JOHN ZIMAN

Bristol University, UK

JOHN CHARAP,

Queen Mary College, London, UK 